\title{
MODIFICATION OF THE NEST-BUILDING HABITS OF POLISTES.
}

\author{
By Phil Rau,
}

Kirkwood, Mo.

The shape of the nests of Polistes is not determined by the iron-clad instincts of the builders. Under pressure of emergency, Polistes builds cell upon cell, regardless of the shape of the nest as a whole. One often finds elongated nests of $P$. pallipes (fig. 1.) that have been built in the space between two boards in a shed. The builder is obliged, if she is to use the chosen location, either to limit the size of her nest or modify it; she has proven herself capable of adapting her handiwork to new requirements.

Figures 2 and 3 show two nests of the same species, $P$. pallipes, that were built in the narrow space behind closed shutters; one was on an old building at Creve Coeur Lake, Mo. and the other at Clifton Terrace, Ill. In the nest in figure 2 where horizontal expansion was impossible, the wasps built a sky-scraper, piling tier upon tier of cells, all of these slanting upward toward the horizontal, whereas the normal cells fall vertically. The nest, illustrated in fig. 3 , likewise adapted to narrow space, shows the same tendency in construction, but in this case some of the cells slant sufficiently toward the vertical to show that the workers were trying to give the larvæ homes which nearly approached the normal position. A third such nest had a dozen. large cells built horizontally in a haphazard way on top.

Not only in $P$. pallipes do we see such digressions, but in $P$. annularis also. I have examined two large nests of $P$. annularis, where I found from three to five cells that were being fashioned about the roof at the base of the petiole. These, however, were not large, and in all probability merely showed the building instinct misdirected, $i$. e. the workers were probably adding paper pulp to strengthen the petiole and so far forgot themselves as to fashion cells at the wrong place. "Gross ist die Macht der Gewohnheit." Certainly P. annularis, in extending her nest, 
does not need to build skyward, for her nests are in the trees, where she has ample space wherein to expand normally.

The $P$. rubiginosis nests were usually built in the dark space between the weatherboarding and the inside wall of an old house. One was also placed in a narrow space between two upright timbers, and as the nest grew to fill the entire space it took on the peculiar oblong shape. But the space was apparently not sufficient, for on the back of the nest a row of 10 cells (arrows in fig. 4) was begun. The shape of the normal nest is probably round with the petiole in the center. In this case, the petiole had not sufficient strength to hold the mass, and as the season neared its close, the nest fell and lodged on a joist below.

Thus, to the credit of at least some species of Polistes, let it be said that wasps do not yield to defeat when the nest has outgrown its quarters, but they make the best of the situation and continue building. Let it be said, too, to the discredit of some members of these species, that they have not the foresight to choose sites large enough to accomodate the growing family, but that too late they discover their cramped quarters.

These nests reveal the formation of a habit which may some day be developed with some degree of permanency. They show that the wasps have discovered, or stumbled upon, the fact that both sides of the wall or roof can, in emergency, be used to support cells. Alas! it is too much to hope that we may in our brief lifetime see the crystallization of a disgression, adaptation or new economy like this into a regular habit. That type of nest, $i . e$., with cells attached to both sides of the main supportingplatform, thus making them open in opposite directions, is made by Belonogaster junceus of the tropics.

One small nest of a $P$. pallipes queen which differed from the normal in its method of attachment to its support was observed. It was only a quarter-inch below the roof of a railway shed, yet it was attached to a vertical timber; hence the petiole, which is usually vertical and straight, made a horizontal beginning and turned sharply downward elbow-wise. It is obvious that a nest could never attain any considerable size in that position.

Vespa builds combs in tiers and Polistes builds but a single 


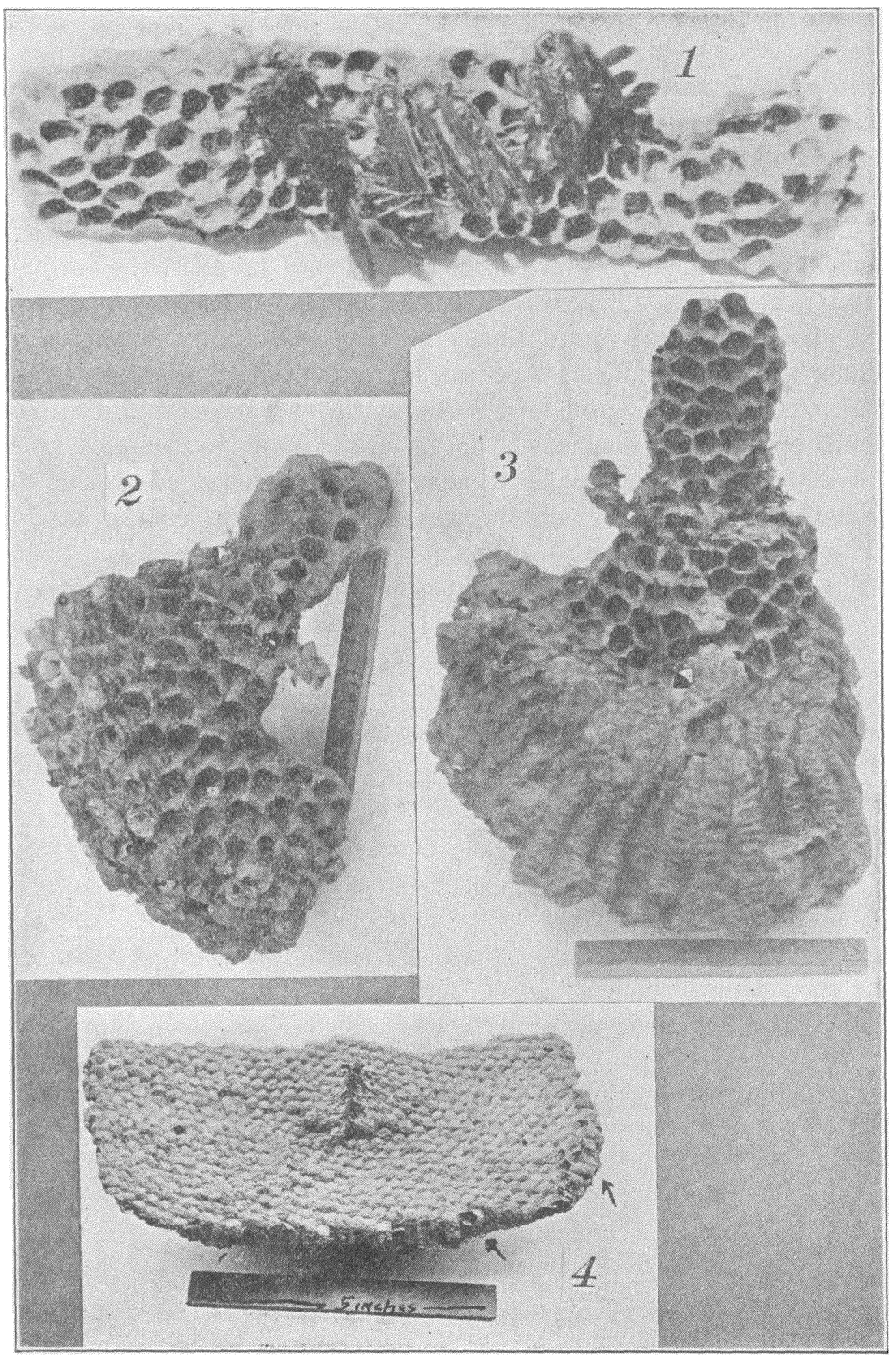

RAU-POLISTES 
comb. One nest of $P$. rubiginosis was built a second year in the same site as the first, in the narrow space between two boards in an old refrigerator car. The result was that the second comb was attached to and below the first, giving the nest the appearance of the combs of Vespa. This was merely an accident due to the narrowness of the space, combined with the persistence of the rubiginosus queens in returning to their old home in the spring. But it is just by such accidents that new habits get a foot-hold. In another place, I found a nest in the narrow space between the inner and outer walls of a barn. Here one tier of cells was built below the other, much after the manner of comb-building in tiers by the Vespine wasps. This may point to the rise and evolution of the habit of arranging combs in tiers. Who knows but that Vespa at one time may have built single combs as do Polistes to-day, and who knows further but that a similar accident of crowding may have caused her to build tier below tier until to-day we have this practice fixed in the habits of the Vespa?

\section{Explanation of PLATE IV.}

Fig. 1. Polistes annularis seeking shelter from the cold in an old nest of Polistes pallipes

Fig. 2. Nest of Polistes pallipes built in a tight corner.

Fig. 3. A sky-scraper nest of Pollistes pallipes.

Fig. 4. Nest of Polistes rubiginosus. 

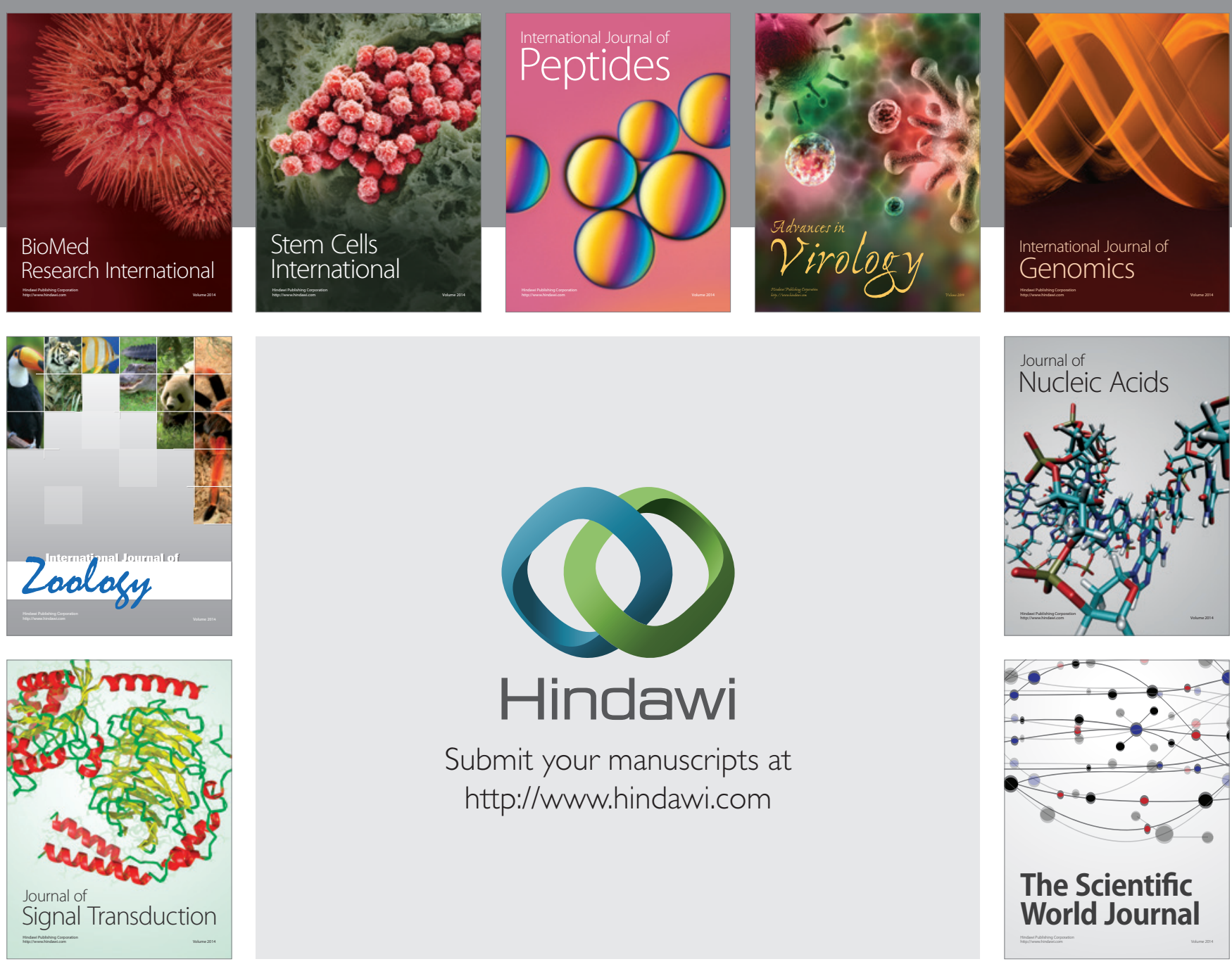

Submit your manuscripts at

http://www.hindawi.com
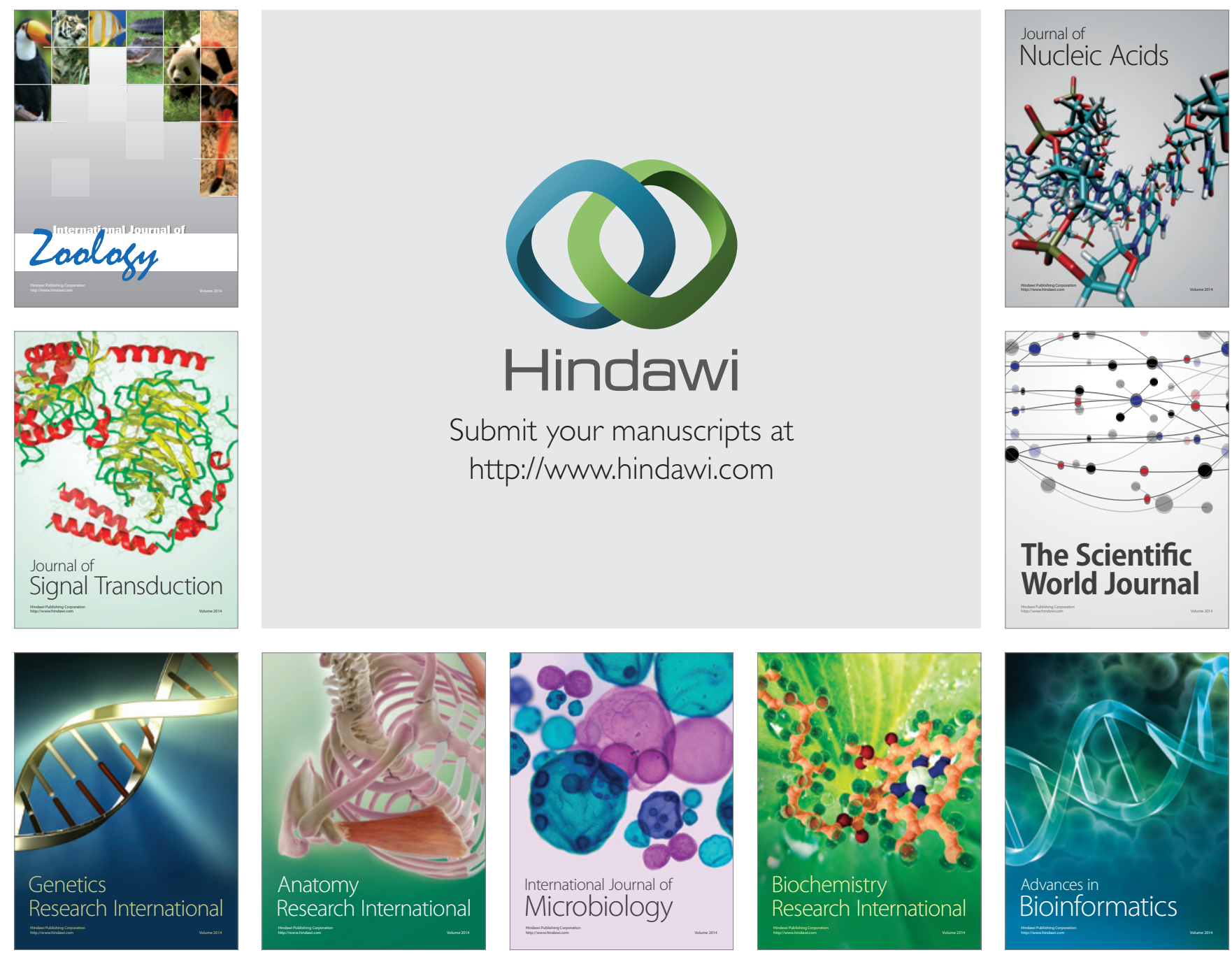

The Scientific World Journal
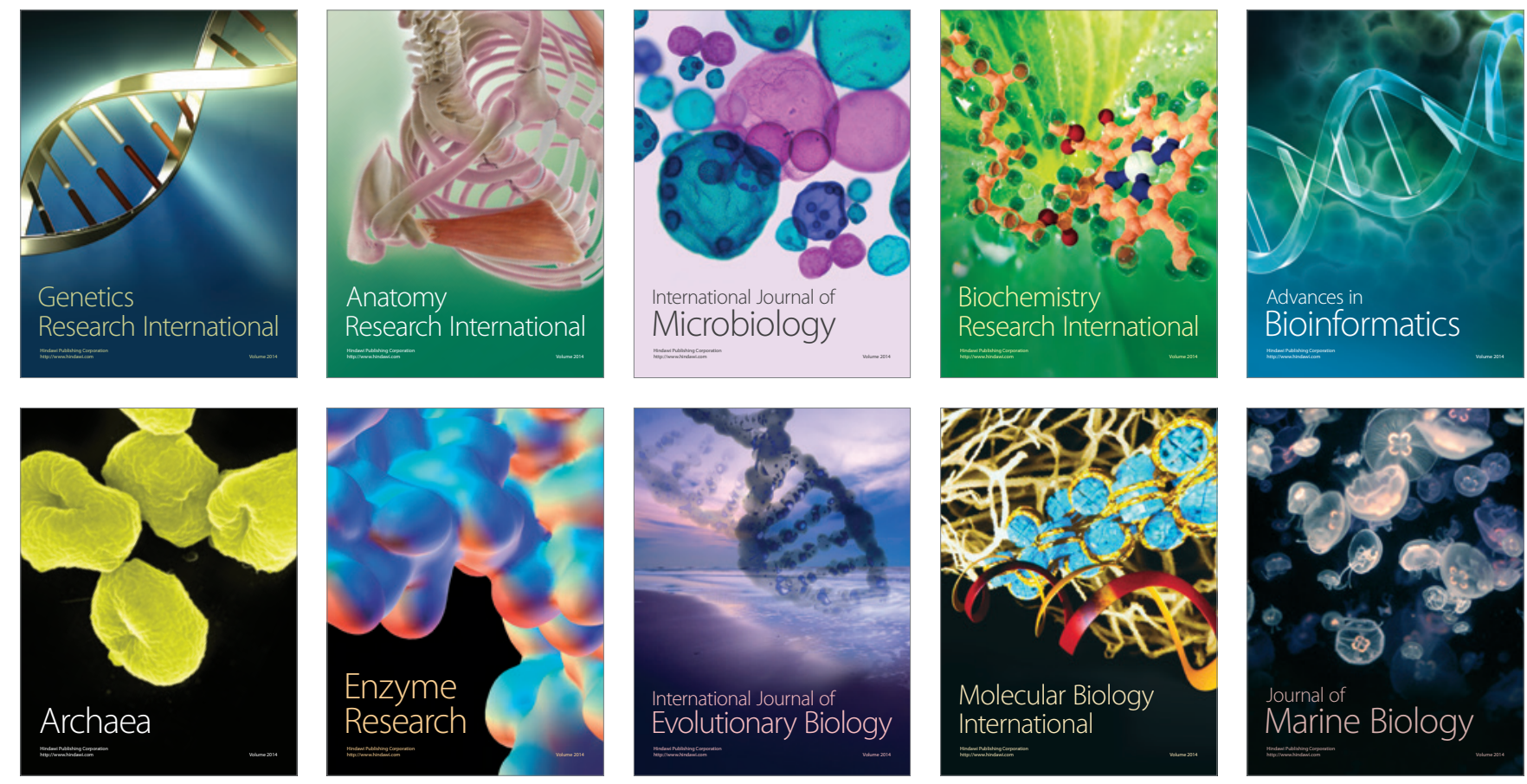